\title{
Sustainability in Business Process Management as an Important Strategic Challenge in Human Resource Management
}

\author{
Silvia Lorincová ${ }^{1, * \mathbb{C}}$, Miloš Čambál ${ }^{2}$, Andrej Miklošík $^{3} \oplus$, Žaneta Balážová ${ }^{4}$, \\ Zdenka Gyurák Babel'ová ${ }^{2}\left(\mathbb{C}\right.$ and Miloš Hitka ${ }^{1}$ (D) \\ 1 Faculty of Wood Sciences and Technology, Technical University in Zvolen, Ul. T. G. Masaryka 24, \\ 96001 Zvolen, Slovakia; hitka@tuzvo.sk \\ 2 Faculty of Materials Science and Technology, Slovak University of Technology, Jána Bottu 2781/25, \\ 91724 Trnava, Slovakia; milos.cambal@stuba.sk (M.Č.); zdenka.babelova@stuba.sk (Z.G.B.) \\ 3 Faculty of Management, Comenius University in Bratislava, Odbojárov 10 P.O.BOX 95, \\ 82005 Bratislava 25, Slovakia; andrej.miklosik@fm.uniba.sk \\ 4 Institute of Foreign Languages, Technical University in Zvolen, Ul. T. G. Masaryka 24, \\ 96001 Zvolen, Slovakia; zaneta.balazova@tuzvo.sk \\ * Correspondence: silvia.lorincova@tuzvo.sk
}

Received: 29 June 2020; Accepted: 18 July 2020; Published: 23 July 2020

\begin{abstract}
The main goal of human resource management (HRM) is to create conditions that allow enterprises to run businesses effectively by following the maximum performance and sustainability of business processes, which are key factors for an enterprise to succeed on the market. For effective management of employees as a part of HRM, systematic employee motivation is necessary because human resources are a key factor for achieving enterprise sustainability. As employees can be motivated by everything stimulating their activity, the aim is to define the importance of employee motivation through the most important motivation factors relating to mutual relationships. The emphasis is put on the identification of statistically significant differences in terms of socio-demographic features of employees. At a significance level of $5 \%$, the statistically significant differences in terms of gender, age, and job were tested further using Tukey's honestly significant difference test. The research results showed a large number of statistically significant differences between individual employee categories. This leads to the conclusion that employers should focus on creating individual motivation programs for employees and not approach employees uniformly because of their various needs. Creating individual motivation programs for employees should respect their needs in terms of gender, age, and job position. Enterprises are recommended to focus their motivation programs on supporting motivation factors related to finance, mutual relationships, and work conditions.
\end{abstract}

Keywords: the development of HRM; sustainable business processes; human capital; sustainable human resource management; motivation; motivation factors

\section{Introduction}

Today's business environment can be properly characterized by using the following terms: Dynamic development, turbulences, unstable markets, knowledge-based enterprises, globalization, sustainability, and competitive environment [1-6]. In order to be successful in such an environment, existing sources must be quickly and effectively connected by enterprises [7-10]. Therefore, personnel management and implementation of its components in human resource management (HRM) play an important role in management of each enterprise [11-13]. As people are the most important asset of 
each enterprise, the main goal of HRM is to create conditions that allow enterprises to run businesses effectively by following the maximum performance and sustainability of business processes, which are key factors for an enterprise to succeed on the market [14-17].

The role of human resources is strategic. In comparison to financial sources, they are able to create competitive advantage. Human resources are a key factor in achieving enterprise sustainability [18,19]. Running a business, its prosperity, and its sustainable development are affected by their quality [20-23]. If a company's top management is aware of the fact that human resources are essential for enterprise development, then HRM can be regarded as a key to success [24].

The basic role of HRM is to ensure the so-called positive behavior of employees. This is a behavior of employees resulting in carrying out the enterprise's strategy and meeting the goals in an effective way. Systematic employee motivation and subsequent motivation processes are necessary for managing the employees effectively [25]. Motivation as one of the basic prerequisites for the success and effectiveness of job performance in relation to the sustainability of business processes is an essential part of the theory of HRM [26]. It is a prerequisite for goal-directed behavior to meet specific needs through determination and inner power [27]. It is also defined as a cognitive decision-making process to monitor the behavior aimed at achieving a specific goal [28]. The ability to motivate employees is regarded as one of the basic skills of managers, instantly affecting the enterprise's success [29,30].

Therefore, the goal of this paper is to define employee motivation through the most important motivation factors relating to mutual relationships that motivate Slovak employees to improve their job performance. Moreover, the significant differences in terms of socio-demographic features of respondents (gender, age, job position) are identified.

\section{Literature Review}

Actual research studies have empirically tested motivation and job performance [31,32]. Further research confirmed that employees can be motivated by everything stimulating their activity, determining the goals and directions [29,33-37]. According to the research of Chatzopoulou et al. [38] and Kampkötter [39], basic salaries and rewards are motivation factors that are important for employees. The research of Brady and King [34], Anguelov et al. [40], and Bakotic and Babic [41] showed that working conditions are one of the main factors of employee motivation. According to Manzoor [42], the personality and behavior of a supervisor are considered important as well. Ogbonna and Harris [43] highlight the importance of motivation in leading to high employee performance according to management level and style. Motivation factors, such as interpersonal relationships, recognition, and work teams, were defined in the research of Raziq and Maulabakhsh [44]. According to Baah and Amoako [45], employees are motivated by (1) the nature of their work, (2) their sense of achievement in work, (3) recognition, (4) responsibility, and (5) opportunities for personal growth and advancement. Khalid et al. [46], Yang [47], and Monusova [48] mentioned that the nature of work processes and working conditions are important for employee motivation. Present research studies show that employees can be motivated in five basic areas relating to finance, relationships, social status, career, and workplace, respectively [49,50].

Employees can be motivated by other factors as well. Employees' opinions on motivation can depend on their socio-demographic profiles. There are studies defining the differences in employee motivation in terms of gender [51-53]. Peterson [54], Joniakova and Blstakova [55], Zemke [56], Bailyn [57], and Buttner [58] found out that men are motivated by economic welfare and professional success at work, while women prefer to work interactively [54], trying to achieve work-family balance [59]. There are also further research studies confirming the differences in employee motivation in terms of age [60-62]. In terms of age, younger employees are motivated more by higher financial rewards, whereas older employees are motivated by accomplishments they have already achieved [63]. According to our previous research, differences in employee motivation in terms of job category have been identified [63-67]. Based on the research of Mikkelsen et al. [64] and Anderson and Pallesen [67], managers perceive as motivational the factors related to finance, as well as recognition and freedom in 
decision-making. The research results of Ngyuyen [65] and Kanfer et al. [66] showed that employees in lower-level jobs are also motivated by financial rewards. Further research has shown the mutual interactions of various factors. The interactions of age, gender, and education were investigated by Nguyen et al. [68]. The interaction between gender and age was studied by Hitka et al. [69]. Three factors and their mutual interactions are selected from various factors.

This paper fills the gap by providing information about the ways of motivating employees in terms of gender, age, and job position. Therefore, the goal of the research is to determine the most important motivation factors relating to relationships, motivating Slovak employees to improve performance, and, especially, identifying significant differences in terms of socio-demographic characteristics (gender, age, job position). The definition of the mutual relations between gender, age, and job position can be regarded as a contribution of this research.

\section{Materials and Methods}

The importance of employee motivation was defined using anonymous questionnaires. The questionnaires were filled in by randomly selected employees hired by enterprises in Slovakia in order to ensure the variability and randomness of respondent selection. This was necessary in order to acquire relevant data. The questionnaire consisted of two parts. Data related to gender, age, and job position were obtained in the first part of the questionnaire. In total, 34,615 employees participated in the questionnaire. The sample is presented in Table 1.

Table 1. Composition of the sample.

\begin{tabular}{|c|c|c|c|c|c|c|c|c|c|c|}
\hline \multirow{2}{*}{\multicolumn{2}{|c|}{$\begin{array}{c}\text { Gender } \\
\text { Age }\end{array}$}} & \multicolumn{4}{|c|}{ Male } & \multicolumn{4}{|c|}{ Female } & \multirow{3}{*}{$\begin{array}{l}\text { Total } \\
3707\end{array}$} \\
\hline & & \multirow{2}{*}{$\begin{array}{l}<30 \\
309\end{array}$} & \multirow{2}{*}{$\begin{array}{l}<40 \\
593\end{array}$} & \multirow{2}{*}{$\begin{array}{l}<50 \\
620\end{array}$} & \multirow{2}{*}{$\frac{50+}{362}$} & \multirow{2}{*}{$\begin{array}{l}<30 \\
371\end{array}$} & \multirow{2}{*}{$\begin{array}{l}<40 \\
578\end{array}$} & \multirow{2}{*}{$\begin{array}{l}<50 \\
548\end{array}$} & \multirow{2}{*}{$\begin{array}{c}50+ \\
326\end{array}$} & \\
\hline & Manager & & & & & & & & & \\
\hline $\begin{array}{c}\text { Job } \\
\text { cateogry }\end{array}$ & BCW & 3187 & 3522 & 2997 & 1641 & 1811 & 2132 & 2089 & 1185 & 18,564 \\
\hline & WCW & 1125 & 1523 & 1132 & 699 & 1574 & 2402 & 2342 & 1547 & 12,344 \\
\hline \multicolumn{2}{|c|}{ Total } & 4621 & 5638 & 4749 & 2702 & 3756 & 5112 & 4979 & 3058 & 34,615 \\
\hline
\end{tabular}

Based on the methodology of Hitka [70], 30 motivation factors divided into five groups were given in the second part of the questionnaire. The motivation factors relating to mutual relationships (atmosphere in the workplace, good work team, communication in the workplace, supervisor's approach), to career aspirations (opportunity to apply one's own ability, career advancement, competences, prestige, individual decision-making, self-actualization, personal growth, recognition), to finance (basic salary, fringe benefits, fair appraisal system), to work conditions (physical effort at work, occupational safety, job security, workload and type of work, information about performance results, working hours, work environment, job performance, mental effort, stress), and to social needs (social benefits, mission of the company, name of the company, region's development, relation to the environment, free time) were analyzed.

The goal was to define the importance of employee motivation through the most important motivation factors relating to mutual relationships that motivate Slovak employees to improve their job performance. The research was aimed at employees aged up to 30, up to 40, up to 50, and 50+. In terms of job position, the focus was on managers, blue-collar workers (BCW), and white-collar workers (WCW). The importance of motivation factors was evaluated by one of the five levels of importance based on the Likert scale ( 5 = very important; $4=$ important; $3=$ neutral; $2=$ little important; $1=$ not important). Firstly, the importance of the motivation factors was defined using the method of weighted arithmetic mean. Subsequently, the significant differences in terms of gender, age, and job were tested further using Tukey's honestly significant difference test at the significance level of $5 \%$. 


\section{Empirical Results}

In the first step, the importance of motivation factors was defined on the basis of obtained values using the method of weighted arithmetic mean. The results of the ten most important motivation factors motivating Slovak employees to improve their job performance are mentioned in Table 2.

Table 2. Importance of motivation factors.

\begin{tabular}{ccc}
\hline No. & Motivation factor & Mean \\
\hline 1. & Basic salary & 4.509 \\
2. & Good work team & 4.427 \\
3. & Atmosphere in the workplace & 4.416 \\
4. & Fair appraisal system & 4.410 \\
5. & Job security & 4.398 \\
6. & Supervisor's approach & 4.370 \\
7. & Fringe benefits & 4.344 \\
8. & Communication in the workplace & 4.256 \\
9. & Working hours & 4.199 \\
10. & Work environment & 4.180 \\
\hline \multicolumn{3}{c}{}
\end{tabular}

Based on the results mentioned in Table 2, it can be seen that basic salary and fair appraisal system were regarded as the two most important motivation factors relating to finance. A good work team and atmosphere in the workplace were regarded as the two most important motivation factors relating to mutual relationships. Job security and working hours were regarded as the two most important motivation factors relating to work conditions. Motivation factors relating to career aspirations and social needs were not perceived as the most important motivation factors motivating Slovak employees to improve their job performance.

In the next step, the two most important motivation factors relating to mutual relationships were tested further using Tukey's honestly significant difference test.

A good work team was perceived as the most important motivation factor relating to mutual relationships. Individual groups of respondents, quantities, and arithmetic means of evaluations of the desired state of the good work team motivation factor at 95\% reliability are shown in Table 3.

Based on the results in Table 3, it was observed that male managers of the age of up to 40 regarded the good work team motivation factor as the most important. With $95 \%$ reliability, Slovak men assessed the studied motivation factor in a range from 4.43 to 4.55 . A good work team was the most important for female white-collar workers aged $50+$. With $95 \%$ reliability, Slovak women assessed the studied motivation factor in the range from 4.54 to 4.60 .

The results mentioned in Table 4 show that it can be stated with $95 \%$ confidence that the greatest significant differences in the good work team motivation factor are due to gender and job position.

The differences between men and women (Figure 1, Table A1) were confirmed by Tukey's honestly significant difference test. Significant differences are highlighted in red. There were differences between male blue-collar workers aged up to 50 and $50+$ and women aged up to 30 and up to 50 in all job positions, apart from the female blue-collar workers aged up to 40 and male blue-collar workers aged $50+$.

The second most important motivation factor relating to mutual relationships was atmosphere in the workplace. Table 5 shows the results.

According to the results, it was stated that in terms of gender, the motivation factor of atmosphere in the workplace was regarded as the most important by male managers of up to age 50 . Those men evaluated the studied motivation factor, with 95\% reliability, in a range between 4.42 and 4.54 . Female managers aged 50+ evaluated the studied motivation factor in a range between 4.50 and 4.65. Additionally, in this case, women of all ages and in all job positions regarded the mentioned motivation 
factor as more important than men did. Following this finding, it can be stated that the motivation factor of atmosphere in the workplace is more important for women than for men.

Table 3. Descriptive statistics of the good work team motivation factor.

\begin{tabular}{|c|c|c|c|c|c|c|c|}
\hline \multirow{2}{*}{ Gender } & \multirow{2}{*}{ Age } & \multirow{2}{*}{ Job Category } & \multirow{2}{*}{ Total } & \multirow{2}{*}{ Mean } & \multirow{2}{*}{$\begin{array}{l}\text { Standard } \\
\text { Deviation }\end{array}$} & \multicolumn{2}{|c|}{ Confidence Interval } \\
\hline & & & & & & $-95.00 \%$ & $-95.00 \%$ \\
\hline \multirow{12}{*}{ Male } & \multirow{3}{*}{$<30$} & manager & 309 & 4.46601942 & 0.827477005 & 4.37339304 & 4.5586458 \\
\hline & & $\mathrm{BCW}$ & 3187 & 4.34326953 & 0.837459302 & 4.31418341 & 4.37235565 \\
\hline & & WCW & 1125 & 4.45422222 & 0.729946888 & 4.41152192 & 4.49692253 \\
\hline & \multirow{3}{*}{$<40$} & manager & 593 & 4.48903879 & 0.739999489 & 4.42935712 & 4.54872046 \\
\hline & & BCW & 3522 & 4.35065304 & 0.790806213 & 4.32452705 & 4.37677903 \\
\hline & & WCW & 1523 & 4.42350624 & 0.698147764 & 4.38841562 & 4.45859685 \\
\hline & \multirow{3}{*}{$<50$} & manager & 620 & 4.44354839 & 0.806900964 & 4.37990951 & 4.50718726 \\
\hline & & BCW & 2997 & 4.32032032 & 0.792254833 & 4.29194472 & 4.34869592 \\
\hline & & WCW & 1132 & 4.39310954 & 0.747566789 & 4.34951422 & 4.43670486 \\
\hline & \multirow{3}{*}{$50+$} & manager & 362 & 4.46685083 & 0.694462087 & 4.39507127 & 4.53863039 \\
\hline & & $\mathrm{BCW}$ & 1641 & 4.32114564 & 0.800821319 & 4.2823708 & 4.35992049 \\
\hline & & WCW & 699 & 4.44778255 & 0.706948792 & 4.39528353 & 4.50028156 \\
\hline \multirow{12}{*}{ Female } & \multirow{3}{*}{$<30$} & manager & 371 & 4.52830189 & 0.713674977 & 4.45544266 & 4.60116111 \\
\hline & & $\mathrm{BCW}$ & 1811 & 4.42241855 & 0.790778974 & 4.38597384 & 4.45886326 \\
\hline & & WCW & 1574 & 4.55146125 & 0.64249377 & 4.51969624 & 4.58322625 \\
\hline & \multirow{3}{*}{$<40$} & manager & 578 & 4.53460208 & 0.686346112 & 4.47853095 & 4.5906732 \\
\hline & & BCW & 2132 & 4.40712946 & 0.766684168 & 4.37456696 & 4.43969195 \\
\hline & & WCW & 2402 & 4.52206495 & 0.673571593 & 4.4951146 & 4.54901529 \\
\hline & \multirow{3}{*}{$<50$} & manager & 548 & 4.49270073 & 0.719245495 & 4.43234799 & 4.55305347 \\
\hline & & BCW & 2089 & 4.42795596 & 0.736762935 & 4.39634349 & 4.45956843 \\
\hline & & WCW & 2342 & 4.52433817 & 0.672303329 & 4.49709583 & 4.55158052 \\
\hline & \multirow{3}{*}{$50+$} & manager & 326 & 4.45705521 & 0.770412024 & 4.37311257 & 4.54099786 \\
\hline & & BCW & 1185 & 4.40337553 & 0.778287761 & 4.35901739 & 4.44773366 \\
\hline & & WCW & 1547 & 4.56625727 & 0.60182916 & 4.5362438 & 4.59627075 \\
\hline
\end{tabular}

Source: Authors' compilation.

Table 4. One-dimensional results of the good work team motivation factor.

\begin{tabular}{cccccc}
\hline Effect & $\begin{array}{c}\text { Degree of } \\
\text { Freedom }\end{array}$ & $\begin{array}{c}\text { Sum of } \\
\text { Squares }\end{array}$ & $\begin{array}{c}\text { Average } \\
\text { Square }\end{array}$ & F-Test & p-Level \\
\hline Absolute term & 1 & $400,110.5$ & $400,110.5$ & $715,981.7$ & 0.000000 \\
Gender & 1 & 29.6 & 29.6 & 53.0 & 0.000000 \\
Age & 3 & 2.4 & 0.8 & 1.4 & 0.229204 \\
Job category & 2 & 93.2 & 46.6 & 83.4 & 0.000000 \\
Gender versus age & 3 & 0.9 & 0.3 & 0.6 & 0.641831 \\
Gender versus job category & 2 & 3.9 & 1.9 & 3.5 & 0.030951 \\
Age versus job category & 6 & 4.5 & 0.7 & 1.3 & 0.235433 \\
Gender versus age versus job category & 6 & 0.9 & 0.2 & 0.3 & 0.945991 \\
Error & 34,591 & $19,330.4$ & & & \\
Total & 34,614 & $19,544.7$ & & & \\
\hline
\end{tabular}

Note: Statistically significant differences are in italic. Source: Authors' compilation.

The effects of gender, age, and job position on the significant differences in the case of the motivation factor of atmosphere in the workplace are mentioned in Table 6. According to the results, it can be seen that gender and job position are two factors affecting motivation the most. 

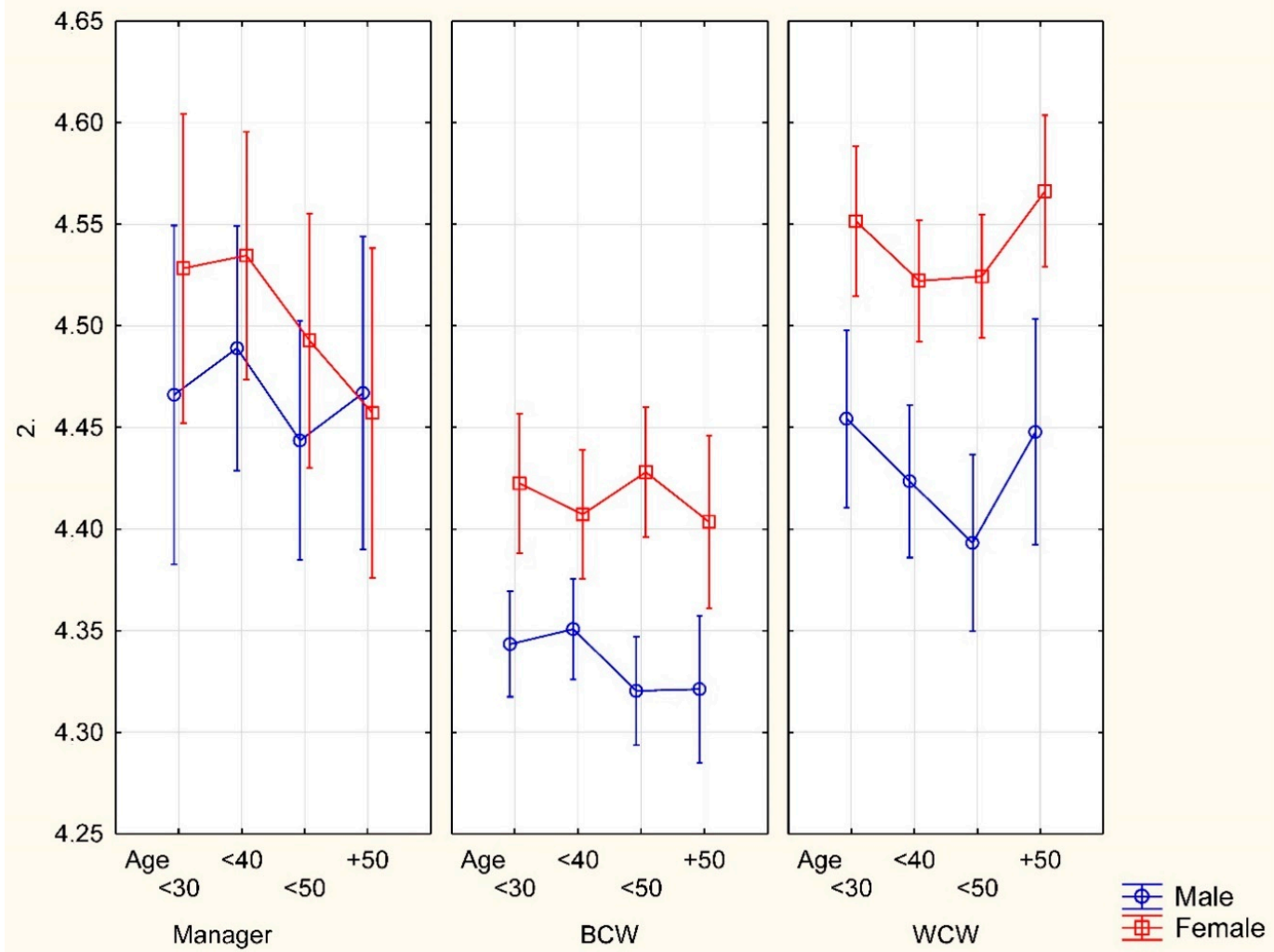

Figure 1. Results of Tukey's honestly significant difference test for the good work team motivation factor.

Table 5. Descriptive statistics of the motivation factor of atmosphere in the workplace.

\begin{tabular}{|c|c|c|c|c|c|c|c|}
\hline \multirow{2}{*}{ Gender } & \multirow{2}{*}{ Age } & \multirow{2}{*}{ Job Category } & \multirow{2}{*}{ Total } & \multirow{2}{*}{ Mean } & \multirow{2}{*}{$\begin{array}{l}\text { Standard } \\
\text { Deviation }\end{array}$} & \multicolumn{2}{|c|}{ Confidence Interval } \\
\hline & & & & & & $-95.00 \%$ & $-95.00 \%$ \\
\hline \multirow{12}{*}{ Male } & \multirow{3}{*}{$<30$} & manager & 309 & 4.469256 & 0.807750 & 4.378837 & 4.559674 \\
\hline & & BCW & 3187 & 4.321305 & 0.874588 & 4.290930 & 4.351681 \\
\hline & & WCW & 1125 & 4.439111 & 0.780705 & 4.393442 & 4.484781 \\
\hline & \multirow{3}{*}{$<40$} & manager & 593 & 4.458685 & 0.748013 & 4.398357 & 4.519013 \\
\hline & & BCW & 3522 & 4.338160 & 0.805803 & 4.311539 & 4.364782 \\
\hline & & WCW & 1523 & 4.393303 & 0.758401 & 4.355184 & 4.431422 \\
\hline & \multirow{3}{*}{$<50$} & manager & 620 & 4.482258 & 0.767688 & 4.421712 & 4.542804 \\
\hline & & BCW & 2997 & 4.304972 & 0.810326 & 4.275949 & 4.333994 \\
\hline & & WCW & 1132 & 4.417845 & 0.730393 & 4.375251 & 4.460438 \\
\hline & \multirow{3}{*}{$50+$} & manager & 362 & 4.458564 & 0.791013 & 4.376804 & 4.540323 \\
\hline & & BCW & 1641 & 4.296161 & 0.816770 & 4.256614 & 4.335708 \\
\hline & & WCW & 699 & 4.417740 & 0.712174 & 4.364853 & 4.470627 \\
\hline \multirow{12}{*}{ Female } & \multirow{3}{*}{$<30$} & manager & 371 & 4.557951 & 0.700394 & 4.486448 & 4.629455 \\
\hline & & BCW & 1811 & 4.421314 & 0.800393 & 4.384426 & 4.458202 \\
\hline & & WCW & 1574 & 4.534943 & 0.677294 & 4.501457 & 4.568428 \\
\hline & \multirow{3}{*}{$<40$} & manager & 578 & 4.493080 & 0.752203 & 4.431628 & 4.554531 \\
\hline & & BCW & 2132 & 4.410882 & 0.795361 & 4.377101 & 4.444662 \\
\hline & & WCW & 2402 & 4.524563 & 0.673485 & 4.497616 & 4.551510 \\
\hline & \multirow{3}{*}{$<50$} & manager & 548 & 4.507299 & 0.709006 & 4.447806 & 4.566793 \\
\hline & & BCW & 2089 & 4.426041 & 0.782600 & 4.392462 & 4.459620 \\
\hline & & WCW & 2342 & 4.502989 & 0.701947 & 4.474545 & 4.531432 \\
\hline & \multirow{3}{*}{$50+$} & manager & 326 & 4.573620 & 0.687768 & 4.498682 & 4.648558 \\
\hline & & BCW & 1185 & 4.389873 & 0.843235 & 4.341814 & 4.437933 \\
\hline & & WCW & 1547 & 4.531351 & 0.641004 & 4.499384 & 4.563318 \\
\hline
\end{tabular}

Source: Authors' compilation. 
Table 6. One-dimensional results of the motivation factor of atmosphere in the workplace.

\begin{tabular}{cccccc}
\hline Effect & $\begin{array}{c}\text { Degree of } \\
\text { Freedom }\end{array}$ & $\begin{array}{c}\text { Sum of } \\
\text { Squares }\end{array}$ & $\begin{array}{c}\text { Average } \\
\text { Square }\end{array}$ & F-Test & p-Level \\
\hline Absolute term & 1 & $399,467.2$ & $399,467.2$ & $671,113.0$ & 0.000000 \\
Gender & 1 & 40.7 & 40.7 & 68.4 & 0.000000 \\
Age & 3 & 1.2 & 0.4 & 0.7 & 0.555673 \\
Job category & 2 & 101.0 & 50.5 & 84.9 & 0.000000 \\
Gender versus age & 3 & 0.7 & 0.2 & 0.4 & 0.748412 \\
Gender versus job category & 2 & 1.1 & 0.5 & 0.9 & 0.405118 \\
Age versus job category & 6 & 3.2 & 0.5 & 0.9 & 0.506409 \\
Gender versus age versus job category & 6 & 3.5 & 0.6 & 1.0 & 0.432415 \\
Error & 34,591 & $20,589.6$ & & & \\
Total & 34,614 & $20,820.4$ & & & \\
\hline
\end{tabular}

Note: Statistically significant differences are highlighted in italic. Source: Authors' compilation.

Based on the results obtained using the Tukey's honestly significant difference test, it can be seen that there is a different way of perceiving the atmosphere in the workplace by men and women (Figure 2, Table A2). Significant differences arise especially between men aged up to 30, up to 50, and $50+$ in job positions as blue-collar workers and women of all ages and in all job positions, apart from female blue-collar workers aged $50+$.
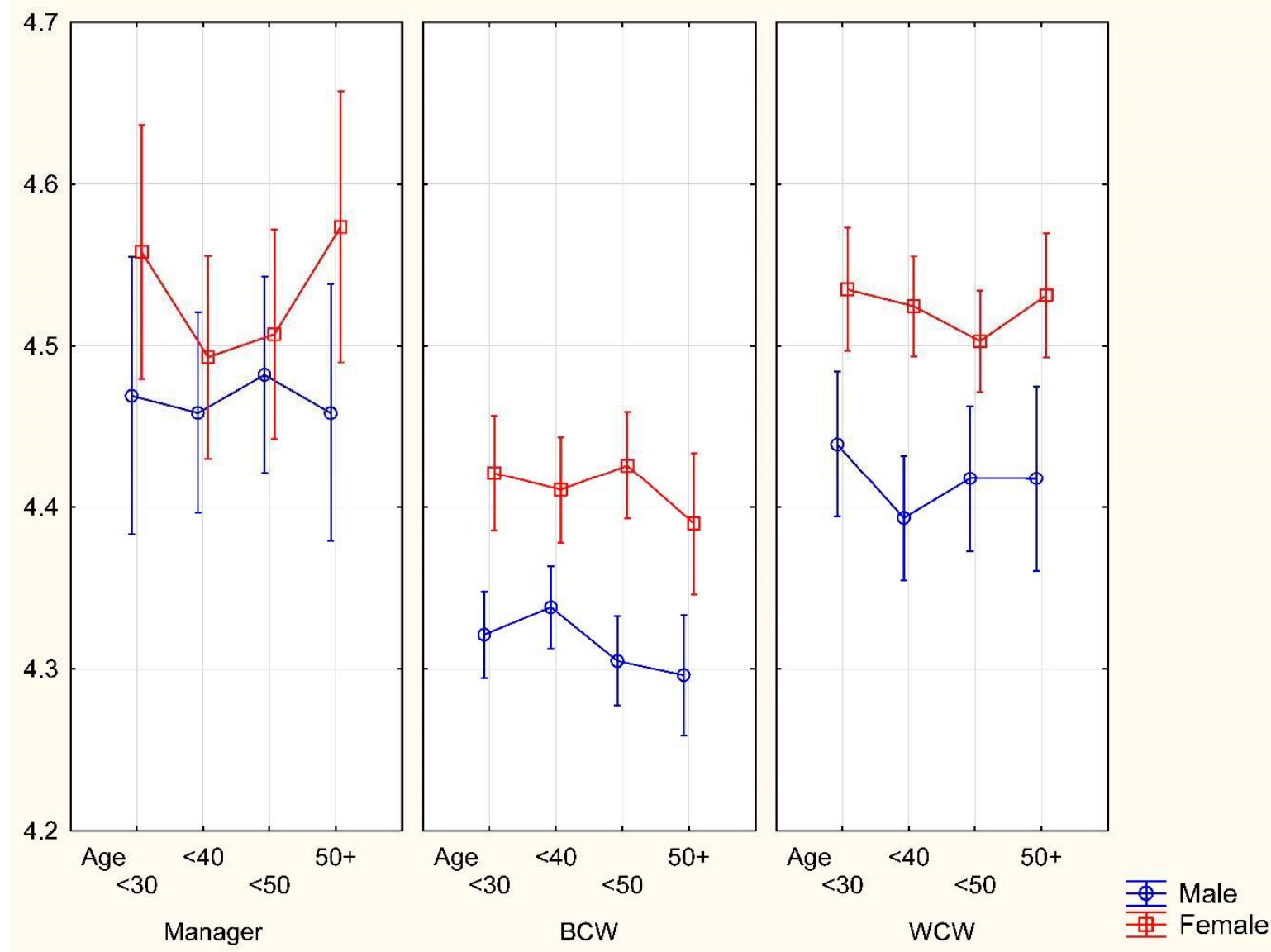

Figure 2. Results of Tukey's honestly significant difference test for the motivation factor of atmosphere in the workplace. 


\section{Discussion}

If an enterprise wants to stay prosperous in today's dynamically changing environment, the management must be focused on employee motivation as one of the most important managerial activities [71-73]. If employees are motivated, their initiatives are endorsed and, subsequently, enterprise goals are effectively achieved and principles of sustainability are incorporated [17,74-79]. In this context, all managers must be familiar with the needs of their employees because employees can be motivated by everything, encouraging their activities and determining their directions and goals $[33,34,36,78,79]$, e.g., basic salary, rewards, personality and behavior of supervisor, level and style of management, work team, interpersonal relationships, recognition, and other factors [34-47]. Based on previous research [54-58], employees' opinions on motivation can change in terms of socio-demographic features. The goal of this research was to determine the importance of employee motivation through the most important motivation factors relating to mutual relationships that motivate Slovak employees to improve their job performance, and especially the identification of the significant differences in terms of socio-demographic features of respondents (gender, age, job position).

Based on the research carried out using a sample set of more than 34,000 employees, it can be seen that a good work team and atmosphere in the workplace were regarded as the most important motivation factors relating to mutual relationships. Motivation factors were tested individually in terms of gender, age, and job position using Tukey's honestly significant difference test.

When analyzing the good work team motivation factor, several statistically significant differences were observed not only between genders, but also between job positions. These significant differences were not caused by the specific effects of gender and job position individually, but, rather, the considerable fluctuation in evaluations of employees resulted from their mutual interaction.

When the motivation factor of atmosphere in the workplace was studied, Tukey's honestly significant difference test showed the formation of a large number of significant differences between individual employee categories in terms of gender, age, and job position. The differences were especially due to gender and age.

Following the results of the research, a large number of statistically significant differences between individual employee categories was observed. Marked similarities between countries in Central Europe according to selected specifications were also confirmed in the research of Hitka et al. [80] and Lizbetinova et al. [81]. The emphasis is put on the factors relating to finance, especially because of the low productivity at work and the low income of the population $[82,83]$. This leads to the conclusion that employers should focus on creating motivation programs for employees as individual parts and should not approach employees uniformly, especially because of the employees' various needs in terms of gender, age, and job position. In order to be effective, a motivation program must reflect employees' needs. Their behavior and performance must be affected in order to move toward the desired direction. Moreover, the motivation program must cover requirements of both the enterprise and the employees. Therefore, based on the obtained results, it is recommended that enterprises focus on supporting the motivation factors relating to finance, mutual relationships, and working conditions.

\section{Conclusions}

Globalization, increasing pressure of competition, and the growing interest in sustainability of business processes have resulted in new trends in the competitive environment, asking for a turning point in the developmental thinking of all employees in an enterprise. At present, providing quality services is not enough for building an enterprise's success. The background of the differences in the competitive advantages of each enterprise can be seen in human resources. Their importance is strategic because they affect enterprise operations, prosperity, and sustainability.

An original contribution of this paper is the definition of employee motivation through the most important motivation factors relating to mutual relationships that motivate Slovak employees to improve their job performance. Moreover, significant differences in terms of socio-demographic features of respondents (gender, age, job position) were identified. 
The research showed that there are differences in motivation factors between Slovak employees in terms of gender, age, and job position. Based on the research results, large numbers of statistically significant differences between individual employee categories were observed. Therefore, a conclusion was drawn that employers should focus on creating individual motivation programs for employees with respect to their needs in terms of gender, age, and job position. It is recommended that enterprises focus their motivation programs on supporting motivation factors related to finance, mutual relationships, and working conditions. At the same time, the fact that employees' opinions on motivation can change over the course of time must be taken into account. Employees' requirements for motivation can also change after meeting their needs. Therefore, the motivation program must be updated and modified regularly to cover the requirements of enterprises as well as employees.

On the basis of the studies analyzing motivation in terms of gender [50-52,57], age [58-60], and job categories [62-65], the managers dealt with motivation factors only partially. Our results can be used in the managers' decision-making processes to create motivation programs because all three areas (age, gender, job category) and their mutual interactions are covered there.

In the future, the focus of the research will be placed on other interactions, not only in terms of gender, age, and job position, but also in terms of education, seniority, or regional affiliation; this can be considered the research limitation. However, further collection of data, as well as deeper investigation, is necessary due to the complexity of interactions.

Author Contributions: Conceptualization, S.L., M.Č., A.M., Ž.B., Z.G.B., and M.H.; methodology, S.L., M.Č., A.M., Ž.B., Z.G.B., and M.H.; data curation, S.L., M.Č., A.M., Ž.B., Z.G.B., and M.H.; writing—original draft, S.L., M.Č., A.M., Ž.B., Z.G.B., and M.H.; visualization, S.L., M.Č., A.M., Ž.B., Z.G.B., and M.H. All authors have read and agreed to the published version of the manuscript.

Funding: The APC was funded by the Ministry of Education, Science, Research and Sport of the Slovak Republic; VEGA project No. 1/0721/20 „Identification of priorities for sustainable human resources management with respect to disadvantaged employees in the context of Industry 4.0.".

Acknowledgments: This paper is a part of projects VEGA No. 1/0721/20, "Identification of priorities for sustainable human resources management with respect to disadvantaged employees in the context of Industry 4.0", KEGA 005TU Z-4/2020 “Economics, Management, and Enterprising in Wood Industry Companies—university textbook with visualization support in virtual space", KEGA 016EU-4/2019 "Innovative learning texts from marketing for secondary schools", and VEGA 1/0737/20 "Consumer Literacy and Intergenerational Changes in Consumer Preferences when Purchasing Slovak Products".

Conflicts of Interest: The authors declare no conflict of interest. 


\section{Appendix A}

Table A1. Tukey's honestly significant difference test for the good work team motivation factor.

\begin{tabular}{|c|c|c|c|c|c|c|c|c|c|c|c|c|c|c|c|c|c|c|c|c|c|c|c|c|c|c|c|}
\hline & & & & $\{\mathbf{1}\}$ & $\{2\}$ & $\{3\}$ & $\{4\}$ & $\{5\}$ & $\{6\}$ & $\{7\}$ & $\{8\}$ & $\{9\}$ & $\{10\}$ & $\{11\}$ & $\{12\}$ & $\{13\}$ & $\{14\}$ & $\{15\}$ & $\{16\}$ & $\{17\}$ & $\{18\}$ & $\{19\}$ & $\{20\}$ & $\{21\}$ & $\{22\}$ & $\{23\}$ & $\{24\}$ \\
\hline Gender & & & & 4.466 & 4.343 & 4.454 & 4.489 & 4.350 & 4.423 & 4.443 & 4.320 & 4.393 & 4.466 & 4.321 & 4.447 & 4.528 & 4.422 & 4.551 & 4.534 & 4.407 & 4.522 & 4.492 & 4.428 & 4.524 & 4.457 & 4.403 & 4.566 \\
\hline \multirow{12}{*}{ Male } & \multirow{3}{*}{$<30$} & Manager & $\{1\}$ & & 0.935 & 1.000 & 1.000 & 0.966 & 1.000 & 1.000 & 0.734 & 1.000 & 1.000 & 0.744 & 1.000 & 1.000 & 1.000 & 0.990 & 1.000 & 1.000 & 1.000 & 1.000 & 1.000 & 1.000 & 1.000 & 1.000 & 0.994 \\
\hline & & $\mathrm{BCW}$ & $\{2\}$ & 0.935 & & 0.073 & 0.119 & 1.000 & 0.319 & 0.776 & 1.000 & 0.997 & 0.859 & 1.000 & 0.586 & 0.114 & 0.189 & 0.000 & 0.003 & 0.445 & 0.000 & 0.136 & 0.046 & 0.000 & 0.961 & 0.958 & 0.000 \\
\hline & & WCW & $\{3\}$ & 1.000 & 0.073 & & 1.000 & 0.145 & 1.000 & 1.000 & 0.005 & 0.962 & 1.000 & 0.006 & 1.000 & 1.000 & 1.000 & 0.242 & 0.980 & 0.999 & 0.893 & 1.000 & 1.000 & 0.858 & 1.000 & 0.996 & 0.065 \\
\hline & \multirow{3}{*}{$<40$} & Manager & $\{4\}$ & 1.000 & 0.119 & 1.000 & & 0.188 & 0.999 & 1.000 & 0.021 & 0.866 & 1.000 & 0.022 & 1.000 & 1.000 & 0.998 & 0.999 & 1.000 & 0.972 & 1.000 & 1.000 & 0.999 & 1.000 & 1.000 & 0.954 & 0.986 \\
\hline & & $\mathrm{BCW}$ & $\{5\}$ & 0.966 & 1.000 & 0.145 & 0.188 & & 0.525 & 0.877 & 0.997 & 1.000 & 0.918 & 1.000 & 0.729 & 0.166 & 0.370 & 0.000 & 0.007 & 0.702 & 0.000 & 0.210 & 0.124 & 0.000 & 0.982 & 0.991 & 0.000 \\
\hline & & WCW & $\{6\}$ & 1.000 & 0.319 & 1.000 & 0.999 & 0.525 & & 1.000 & 0.028 & 1.000 & 1.000 & 0.031 & 1.000 & 0.968 & 1.000 & 0.001 & 0.656 & 1.000 & 0.050 & 0.998 & 1.000 & 0.037 & 1.000 & 1.000 & 0.000 \\
\hline & \multirow{3}{*}{$<50$} & Manager & $\{7\}$ & 1.000 & 0.776 & 1.000 & 1.000 & 0.877 & 1.000 & & 0.360 & 1.000 & 1.000 & 0.374 & 1.000 & 0.998 & 1.000 & 0.644 & 0.925 & 1.000 & 0.978 & 1.000 & 1.000 & 0.969 & 1.000 & 1.000 & 0.369 \\
\hline & & $\mathrm{BCW}$ & $\{8\}$ & 0.734 & 1.000 & 0.005 & 0.021 & 0.997 & 0.028 & 0.360 & & 0.805 & 0.567 & 1.000 & 0.188 & 0.030 & 0.009 & 0.000 & 0.000 & 0.029 & 0.000 & 0.027 & 0.001 & 0.000 & 0.794 & 0.513 & 0.000 \\
\hline & & WCW & $\{9\}$ & 1.000 & 0.997 & 0.962 & 0.866 & 1.000 & 1.000 & 1.000 & 0.805 & & 1.000 & 0.822 & 1.000 & 0.704 & 1.000 & 0.000 & 0.174 & 1.000 & 0.009 & 0.868 & 1.000 & 0.007 & 1.000 & 1.000 & 0.000 \\
\hline & \multirow{3}{*}{$50+$} & Manager & $\{10\}$ & 1.000 & 0.859 & 1.000 & 1.000 & 0.918 & 1.000 & 1.000 & 0.567 & 1.000 & & 0.579 & 1.000 & 1.000 & 1.000 & 0.998 & 1.000 & 1.000 & 1.000 & 1.000 & 1.000 & 1.000 & 1.000 & 1.000 & 0.985 \\
\hline & & $\mathrm{BCW}$ & $\{11\}$ & 0.744 & 1.000 & 0.006 & 0.022 & 1.000 & 0.031 & 0.374 & 1.000 & 0.822 & 0.579 & & 0.199 & 0.031 & 0.021 & 0.000 & 0.000 & 0.142 & 0.000 & 0.029 & 0.009 & 0.000 & 0.803 & 0.534 & 0.000 \\
\hline & & WCW & $\{12\}$ & 1.000 & 0.586 & 1.000 & 1.000 & 0.729 & 1.000 & 1.000 & 0.188 & 1.000 & 1.000 & 0.199 & & 0.999 & 1.000 & 0.603 & 0.954 & 1.000 & 0.976 & 1.000 & 1.000 & 0.967 & 1.000 & 1.000 & 0.318 \\
\hline \multirow{12}{*}{ Female } & \multirow{3}{*}{$<30$} & Manager & $\{13\}$ & 1.000 & 0.114 & 1.000 & 1.000 & 0.166 & 0.968 & 0.998 & 0.030 & 0.704 & 1.000 & 0.031 & 0.999 & & 0.964 & 1.000 & 1.000 & 0.867 & 1.000 & 1.000 & 0.980 & 1.000 & 1.000 & 0.830 & 1.000 \\
\hline & & $\mathrm{BCW}$ & $\{14\}$ & 1.000 & 0.189 & 1.000 & 0.998 & 0.370 & 1.000 & 1.000 & 0.009 & 1.000 & 1.000 & 0.021 & 1.000 & 0.964 & & 0.000 & 0.636 & 1.000 & 0.013 & 0.998 & 1.000 & 0.009 & 1.000 & 1.000 & 0.000 \\
\hline & & WCW & $\{15\}$ & 0.990 & 0.000 & 0.242 & 0.999 & 0.000 & 0.001 & 0.644 & 0.000 & 0.000 & 0.998 & 0.000 & 0.603 & 1.000 & 0.000 & & 1.000 & 0.000 & 1.000 & 1.000 & 0.001 & 1.000 & 0.996 & 0.000 & 1.000 \\
\hline & \multirow{3}{*}{$<40$} & Manager & $\{16\}$ & 1.000 & 0.003 & 0.980 & 1.000 & 0.007 & 0.656 & 0.925 & 0.000 & 0.174 & 1.000 & 0.000 & 0.954 & 1.000 & 0.636 & 1.000 & & 0.363 & 1.000 & 1.000 & 0.732 & 1.000 & 1.000 & 0.304 & 1.000 \\
\hline & & $\mathrm{BCW}$ & $\{17\}$ & 1.000 & 0.445 & 0.999 & 0.972 & 0.702 & 1.000 & 1.000 & 0.029 & 1.000 & 1.000 & 0.142 & 1.000 & 0.867 & 1.000 & 0.000 & 0.363 & & 0.000 & 0.970 & 1.000 & 0.000 & 1.000 & 1.000 & 0.000 \\
\hline & & WCW & $\{18\}$ & 1.000 & 0.000 & 0.893 & 1.000 & 0.000 & 0.050 & 0.978 & 0.000 & 0.009 & 1.000 & 0.000 & 0.976 & 1.000 & 0.013 & 1.000 & 1.000 & 0.000 & & 1.000 & 0.010 & 1.000 & 1.000 & 0.023 & 0.995 \\
\hline & \multirow{3}{*}{$<50$} & Manager & $\{19\}$ & 1.000 & 0.136 & 1.000 & 1.000 & 0.210 & 0.998 & 1.000 & 0.027 & 0.868 & 1.000 & 0.029 & 1.000 & 1.000 & 0.998 & 1.000 & 1.000 & 0.970 & 1.000 & & 0.999 & 1.000 & 1.000 & 0.953 & 0.996 \\
\hline & & BCW & $\{20\}$ & 1.000 & 0.046 & 1.000 & 0.999 & 0.124 & 1.000 & 1.000 & 0.001 & 1.000 & 1.000 & 0.009 & 1.000 & 0.980 & 1.000 & 0.001 & 0.732 & 1.000 & 0.010 & 0.999 & & 0.007 & 1.000 & 1.000 & 0.000 \\
\hline & & WCW & $\{21\}$ & 1.000 & 0.000 & 0.858 & 1.000 & 0.000 & 0.037 & 0.969 & 0.000 & 0.007 & 1.000 & 0.000 & 0.967 & 1.000 & 0.009 & 1.000 & 1.000 & 0.000 & 1.000 & 1.000 & 0.007 & & 1.000 & 0.017 & 0.998 \\
\hline & \multirow{3}{*}{$50+$} & Manager & $\{22\}$ & 1.000 & 0.961 & 1.000 & 1.000 & 0.982 & 1.000 & 1.000 & 0.794 & 1.000 & 1.000 & 0.803 & 1.000 & 1.000 & 1.000 & 0.996 & 1.000 & 1.000 & 1.000 & 1.000 & 1.000 & 1.000 & & 1.000 & 0.975 \\
\hline & & $\mathrm{BCW}$ & $\{23\}$ & 1.000 & 0.958 & 0.996 & 0.954 & 0.991 & 1.000 & 1.000 & 0.513 & 1.000 & 1.000 & 0.534 & 1.000 & 0.830 & 1.000 & 0.000 & 0.304 & 1.000 & 0.023 & 0.953 & 1.000 & 0.017 & 1.000 & & 0.000 \\
\hline & & WCW & $\{24\}$ & 0.994 & 0.000 & 0.065 & 0.986 & 0.000 & 0.000 & 0.369 & 0.000 & 0.000 & 0.985 & 0.000 & 0.318 & 1.000 & 0.000 & 1.000 & 1.000 & 0.000 & 0.995 & 0.996 & 0.000 & 0.998 & 0.975 & 0.000 & \\
\hline
\end{tabular}

Note: Statistically significant differences are highlighted in italic. Source: Authors' compilation. 
Table A2. Tukey's honestly significant difference test for the motivation factor of atmosphere in the workplace.

\begin{tabular}{|c|c|c|c|c|c|c|c|c|c|c|c|c|c|c|c|c|c|c|c|c|c|c|c|c|c|c|c|}
\hline \multirow{2}{*}{ Gender } & \multirow{2}{*}{ Age } & \multirow{2}{*}{$\begin{array}{c}\text { Job } \\
\text { Category }\end{array}$} & \multirow{2}{*}{ Mean } & $\{1\}$ & $\{2\}$ & $\{3\}$ & $\{4\}$ & $\{5\}$ & $\{6\}$ & $\{7\}$ & $\{8\}$ & $\{9\}$ & $\{10\}$ & $\{11\}$ & $\{12\}$ & $\{13\}$ & $\{14\}$ & $\{15\}$ & $\{16\}$ & $\{17\}$ & $\{18\}$ & $\{19\}$ & $\{20\}$ & $\{21\}$ & $\{22\}$ & $\{23\}$ & $\{24\}$ \\
\hline & & & & 4.469 & 4.321 & 4.439 & 4.458 & 4.338 & 4.393 & 4.482 & 4.305 & 4.417 & 4.458 & 4.296 & 4.417 & 4.558 & 4.421 & 4.534 & 4.493 & 4.410 & 4.524 & 4.507 & 4.426 & 4.503 & 4.573 & 4.389 & 4.531 \\
\hline \multirow{12}{*}{ Male } & \multirow{3}{*}{$<30$} & Manager & $\{1\}$ & & 0.761 & 1.000 & 1.000 & 0.910 & 1.000 & 1.000 & 0.559 & 1.000 & 1.000 & 0.446 & 1.000 & 0.999 & 1.000 & 1.000 & 1.000 & 1.000 & 1.000 & 1.000 & 1.000 & 1.000 & 0.993 & 1.000 & 1.000 \\
\hline & & $\mathrm{BCW}$ & $\{2\}$ & 0.761 & & 0.053 & 0.253 & 1.000 & 0.617 & 0.044 & 1.000 & 0.309 & 0.755 & 1.000 & 0.793 & 0.007 & 0.020 & 0.000 & 0.030 & 0.029 & 0.000 & 0.014 & 0.003 & 0.000 & 0.007 & 0.888 & 0.000 \\
\hline & & WCW & $\{3\}$ & 1.000 & 0.053 & & 1.000 & 0.232 & 0.999 & 1.000 & 0.008 & 1.000 & 1.000 & 0.003 & 1.000 & 0.915 & 1.000 & 0.330 & 1.000 & 1.000 & 0.575 & 0.999 & 1.000 & 0.956 & 0.858 & 0.998 & 0.410 \\
\hline & \multirow{3}{*}{$<40$} & Manager & $\{4\}$ & 1.000 & 0.253 & 1.000 & & 0.524 & 0.999 & 1.000 & 0.096 & 1.000 & 1.000 & 0.052 & 1.000 & 0.988 & 1.000 & 0.992 & 1.000 & 1.000 & 0.999 & 1.000 & 1.000 & 1.000 & 0.969 & 0.998 & 0.996 \\
\hline & & BCW & $\{5\}$ & 0.910 & 1.000 & 0.232 & 0.524 & & 0.954 & 0.144 & 0.994 & 0.709 & 0.915 & 0.998 & 0.964 & 0.021 & 0.163 & 0.000 & 0.101 & 0.247 & 0.000 & 0.051 & 0.043 & 0.000 & 0.020 & 0.995 & 0.000 \\
\hline & & WCW & $\{6\}$ & 1.000 & 0.617 & 0.999 & 0.999 & 0.954 & & 0.938 & 0.202 & 1.000 & 1.000 & 0.084 & 1.000 & 0.357 & 1.000 & 0.000 & 0.872 & 1.000 & 0.001 & 0.717 & 1.000 & 0.018 & 0.304 & 1.000 & 0.000 \\
\hline & \multirow{3}{*}{$<50$} & Manager & $\{7\}$ & 1.000 & 0.044 & 1.000 & 1.000 & 0.144 & 0.938 & & 0.011 & 0.999 & 1.000 & 0.005 & 0.999 & 1.000 & 1.000 & 1.000 & 1.000 & 0.996 & 1.000 & 1.000 & 1.000 & 1.000 & 0.998 & 0.911 & 1.000 \\
\hline & & BCW & $\{8\}$ & 0.559 & 1.000 & 0.008 & 0.096 & 0.994 & 0.202 & 0.011 & & 0.083 & 0.534 & 1.000 & 0.490 & 0.002 & 0.001 & 0.000 & 0.008 & 0.002 & 0.000 & 0.003 & 0.000 & 0.000 & 0.002 & 0.533 & 0.000 \\
\hline & & WCW & $\{9\}$ & 1.000 & 0.309 & 1.000 & 1.000 & 0.709 & 1.000 & 0.999 & 0.083 & & 1.000 & 0.034 & 1.000 & 0.696 & 1.000 & 0.055 & 0.994 & 1.000 & 0.143 & 0.966 & 1.000 & 0.576 & 0.615 & 1.000 & 0.078 \\
\hline & & Manager & $\{10\}$ & 1.000 & 0.755 & 1.000 & 1.000 & 0.915 & 1.000 & 1.000 & 0.534 & 1.000 & & 0.412 & 1.000 & 0.990 & 1.000 & 1.000 & 1.000 & 1.000 & 1.000 & 1.000 & 1.000 & 1.000 & 0.969 & 1.000 & 1.000 \\
\hline & $50+$ & BCW & $\{11\}$ & 0.446 & 1.000 & 0.003 & 0.052 & 0.998 & 0.084 & 0.005 & 1.000 & 0.034 & 0.412 & & 0.330 & 0.001 & 0.001 & 0.000 & 0.003 & 0.005 & 0.000 & 0.001 & 0.000 & 0.000 & 0.001 & 0.323 & 0.000 \\
\hline & & WCW & $\{12\}$ & 1.000 & 0.793 & 1.000 & 1.000 & 0.964 & 1.000 & 0.999 & 0.490 & 1.000 & 1.000 & 0.330 & & 0.695 & 1.000 & 0.406 & 0.994 & 1.000 & 0.606 & 0.965 & 1.000 & 0.927 & 0.613 & 1.000 & 0.474 \\
\hline \multirow{12}{*}{ Female } & \multirow{3}{*}{$<30$} & Manager & $\{13\}$ & 0.999 & 0.007 & 0.915 & 0.988 & 0.021 & 0.357 & 1.000 & 0.002 & 0.696 & 0.990 & 0.001 & 0.695 & & 0.741 & 1.000 & 1.000 & 0.600 & 1.000 & 1.000 & 0.798 & 1.000 & 1.000 & 0.315 & 1.000 \\
\hline & & BCW & $\{14\}$ & 1.000 & 0.020 & 1.000 & 1.000 & 0.163 & 1.000 & 1.000 & 0.001 & 1.000 & 1.000 & 0.001 & 1.000 & 0.741 & & 0.008 & 0.997 & 1.000 & 0.012 & 0.978 & 1.000 & 0.189 & 0.660 & 1.000 & 0.015 \\
\hline & & WCW & $\{15\}$ & 1.000 & 0.000 & 0.330 & 0.992 & 0.000 & 0.000 & 1.000 & 0.000 & 0.055 & 1.000 & 0.000 & 0.406 & 1.000 & 0.008 & & 1.000 & 0.002 & 1.000 & 1.000 & 0.016 & 1.000 & 1.000 & 0.001 & 1.000 \\
\hline & \multirow{3}{*}{$<40$} & Manager & $\{16\}$ & 1.000 & 0.030 & 1.000 & 1.000 & 0.101 & 0.872 & 1.000 & 0.008 & 0.994 & 1.000 & 0.003 & 0.994 & 1.000 & 0.997 & 1.000 & & 0.982 & 1.000 & 1.000 & 0.999 & 1.000 & 1.000 & 0.831 & 1.000 \\
\hline & & BCW & $\{17\}$ & 1.000 & 0.029 & 1.000 & 1.000 & 0.247 & 1.000 & 0.996 & 0.002 & 1.000 & 1.000 & 0.005 & 1.000 & 0.600 & 1.000 & 0.002 & 0.982 & & 0.000 & 0.926 & 1.000 & 0.020 & 0.522 & 1.000 & 0.003 \\
\hline & & WCW & $\{18\}$ & 1.000 & 0.000 & 0.575 & 0.999 & 0.000 & 0.001 & 1.000 & 0.000 & 0.143 & 1.000 & 0.000 & 0.606 & 1.000 & 0.012 & 1.000 & 1.000 & 0.000 & & 1.000 & 0.008 & 1.000 & 1.000 & 0.005 & 1.000 \\
\hline & \multirow{3}{*}{$<50$} & Manager & $\{19\}$ & 1.000 & 0.014 & 0.999 & 1.000 & 0.051 & 0.717 & 1.000 & 0.003 & 0.966 & 1.000 & 0.001 & 0.965 & 1.000 & 0.978 & 1.000 & 1.000 & 0.926 & 1.000 & & 0.989 & 1.000 & 1.000 & 0.661 & 1.000 \\
\hline & & BCW & $\{20\}$ & 1.000 & 0.003 & 1.000 & 1.000 & 0.043 & 1.000 & 1.000 & 0.000 & 1.000 & 1.000 & 0.000 & 1.000 & 0.798 & 1.000 & 0.016 & 0.999 & 1.000 & 0.008 & 0.989 & & 0.172 & 0.720 & 1.000 & 0.029 \\
\hline & & WCW & $\{21\}$ & 1.000 & 0.000 & 0.956 & 1.000 & 0.000 & 0.018 & 1.000 & 0.000 & 0.576 & 1.000 & 0.000 & 0.927 & 1.000 & 0.189 & 1.000 & 1.000 & 0.020 & 1.000 & 1.000 & 0.172 & & 1.000 & 0.063 & 1.000 \\
\hline & \multirow{3}{*}{$50+$} & Manager & $\{22\}$ & 0.993 & 0.007 & 0.858 & 0.969 & 0.020 & 0.304 & 0.998 & 0.002 & 0.615 & 0.969 & 0.001 & 0.613 & 1.000 & 0.660 & 1.000 & 1.000 & 0.522 & 1.000 & 1.000 & 0.720 & 1.000 & & 0.268 & 1.000 \\
\hline & & $\mathrm{BCW}$ & $\{23\}$ & 1.000 & 0.888 & 0.998 & 0.998 & 0.995 & 1.000 & 0.911 & 0.533 & 1.000 & 1.000 & 0.323 & 1.000 & 0.315 & 1.000 & 0.001 & 0.831 & 1.000 & 0.005 & 0.661 & 1.000 & 0.063 & 0.268 & & 0.002 \\
\hline & & WCW & $\{24\}$ & 1.000 & 0.000 & 0.410 & 0.996 & 0.000 & 0.000 & 1.000 & 0.000 & 0.078 & 1.000 & 0.000 & 0.474 & 1.000 & 0.015 & 1.000 & 1.000 & 0.003 & 1.000 & 1.000 & 0.029 & 1.000 & 1.000 & 0.002 & \\
\hline
\end{tabular}

Note: Statistically significant differences are highlighted in italic. Source: Authors' compilation. 


\section{References}

1. Laužikas, M.; Miliūtè, A. Impacts of modern technologies on sustainable communication of civil service organizations. Entrep. Sustain. Issues 2020, 7, 2494-2509. [CrossRef]

2. Pogodina, T.V.; Muzhzhavleva, T.V.; Udaltsova, N.L. Strategic management of the competitiveness of industrial companies in an unstable economy. Entrep. Sustain. Issues 2020, 7, 1555-1564. [CrossRef]

3. Kohnová, L.; Papula, J.; Salajová, N. Internal factors supporting business and technological transformation in the context of industry 4.0. Bus. Theory Pract. 2019, 20, 137-245. [CrossRef]

4. Nedeliaková, E.; Kuka, A.; Sulko, P.; Hranický, M. An Innovative Approach to Monitoring the Synergies of Extraordinary Events in Rail Transport. In Proceedings of the 22nd International Scientific on Conference Transport Means 2018, Trakai Resort and SPAGedimino, Trakai, Lithuania, 3-5 October 2018.

5. Bajzikova, L.; Novackova, D.; Saxunova, D. Globalization in the Case of Automobile Industry in Slovakia. In Proceedings of the 30th International Business Information Management Association Conference, IBIMA 2017-Vision 2020: Sustainable Economic development, Innovation Management, and Global Growth, Madrid, Spain, 8-9 November 2017.

6. Stacho, Z.; Stachova, K. Outplacement as Part of Human Resource Management. In Proceedings of the 9th International Scientific Conference on Business Economics and Management, Izmir, Turkey, 15-16 October 2015.

7. Nyvlt, V. The Role of Managing Knowledge and Information in BIM Implementation Processes in the Czech Republic. In Proceedings of the International Scientific Conference Building Defects, Ceske Budejovice, Czech Republic, 29-30 November 2018.

8. S Štarchoň, P.; Weberová, D.; Ližbetinová, L. Clustering Czech Consumers According to their Spontaneous Awareness of Foreign Brands. In Proceedings of the 29th International Business Information Management Association Conference Education Excellence and Innovation Management through Vision 2020: From Regional Development Sustainability to Global Economic Growth, Vienna, Austria, 3-4 May 2017.

9. Sheehan, C.; De Cieri, H.; Cooper, B.; Shea, T. Strategic implications of HR role management in a dynamic environment. Pers. Rev. 2016, 45, 353-373. [CrossRef]

10. Urbancova, H.; Vnouckova, L.; Laboutkova, S. Knowledge transfer in a knowledge-based economy. E M Ekon. A Manag. 2016, 19, 73-86. [CrossRef]

11. Palus, H.; Parobek, J.; Dzian, M.; Simo-Svrcek, S.; Krahulcova, M. How companies in the wood supply chain perceive the forest certification. Acta Fac. Xylologiae Zvolen Publica Slovaca 2019, 61, 155-165. [CrossRef]

12. Koval'ová, M.; Hvolková, L.; Klement, L.; Klementová, V. Innovation strategies in the Slovak enterprises. Acta Oeconomica Univ. Selye 2018, 7, 79-89.

13. Weberová, D.; Ližbetinová, L. Consumer Attitudes Towards Brands in Relation to Price. In Proceedings of the 27th International Business Information Management Association Conference Innovation Management and Education Excellence Vision 2020 from Regional Development Sustainability to Global Economic Growth, Milan, Italy, 4-5 May 2016.

14. Kleprlík, J.; Talácko, V. Possibilities how to solve the insufficient number of professional drivers. Perner's Contacts 2019, 19, 81-93.

15. Dominguez, N. SME Internationalization Strategies: Innovation to Conquer New Markets; Wiley Backwell: Hoboken, NJ, USA, 2018.

16. Nemec, M.; Kristak, L.; Hockicko, P.; Danihelova, Z.; Velmovska, K. Application of innovative P\&E method at technical universities in Slovakia. Eurasia J. Math. Sci. Technol. Educ. 2017, 13, 2329-2349. [CrossRef]

17. Graa, A.; Abdelhak, S. A review of branding strategy for small and medium enterprises. Acta Oeconomica Univ. Selye 2016, 5, 67-72.

18. Jung, H.S.; Seo, K.H.; Yoon, H.H. The importance of leader integrity on family restaurant employees' engagement and organizational citizenship behaviors: Exploring sustainability of employees' generational differences. Sustainability 2020, 12, 2504. [CrossRef]

19. Kucharčíková, A.; Mičiak, M. Human capital management in transport enterprises with the acceptance of sustainable development in the Slovak Republic. Sustainability 2018, 10, 2530. [CrossRef]

20. Stankevičiūté, Ž.; Savanevičiené, A. Designing sustainable HRM: The core characteristics of emerging field. Sustainability 2018, 10, 4798. [CrossRef] 
21. Szierbowski-Seibel, K. Strategic human resource management and its impact on performance-Do Chinese organizations adopt appropriate HRM policies? J. Chin. Hum. Resour. Manag. 2018, 9, 62-76. [CrossRef]

22. Stacho, Z.; Stachova, K. The Extent of Education of Employees in Organisations Operating in Slovakia. In Proceedings of the 12th International Conference on Efficiency and Responsibility in Education, Prague, Czech Republic, 4-5 June 2015.

23. Kropivšek, J.; Jelačić, D.; Grošelj, P. Motivating employees of Slovenian and Croatian wood-industry companies in times of economic downturn. Drv. Ind. 2011, 62, 97-103. [CrossRef]

24. Zaborova, E.; Markova, T. Human Capital as a Factor of Regional Development. In Proceedings of the 12th International Days of Statistics and Economics, Prague, Czech Republic, 6-8 September 2018.

25. Stachova, K.; Stacho, Z.; Blstakova, J.; Hlatká, M.; Kapustina, L.M. Motivation of employees for creativity as a form of support to manage innovation processes in transportation-logistics companies. Nase More 2018, 65, 180-186. [CrossRef]

26. Sánchez-Sellero, M.C.; Sánchez-Sellero, P.; Cruz-González, M.M.; Sánchez-Sellero, F.J. Determinants of job satisfaction in the spanish wood and paper industries: A comparative study across spain. Drv. Ind. 2018, 69, 71-80. [CrossRef]

27. Williams, R. How to Motivate Employees; Psychology Today: New York, NY, USA, 2013.

28. David, A.; Anderzej, A. Organisational Behavior, 7th ed.; Pearson: London, UK, 2010.

29. Horváth, Z.; Hollósy, V.G. The revision of Hungarian public service motivation (PSM) model. Cent. Eur. J. Labour Law Pers. Manag. 2019, 2, 17-28. [CrossRef]

30. Kontodimopoulos, N.; Paleologou, V.; Niakas, D. Identifying important motivational factors for professionals in Greek hospitals. BMC Health Serv. Res. 2009, 9, 164. [CrossRef]

31. Halbesleben, J.R.B.; Bowler, W.M. Emotional exhaustion and job performance: The mediating role of motivation. J. Appl. Psychol. 2007, 92, 93-106. [CrossRef]

32. Barrick, M.R.; Stewart, G.L.; Piotrowski, M. Personality and job performance: Test of the mediating effects of motivation among sales representatives. J. Appl. Psychol. 2002, 87, 43-51. [CrossRef] [PubMed]

33. Kimengsi, J.N.; Bhusal, P.; Aryal, A.; Fernandez, M.V.B.C.; Owusu, R.; Chaudhary, A.; Nielsen, W. What (de) motivates forest users' participation in co-management? Evidence from Nepal. Forests 2019, 10, 512. [CrossRef]

34. Brady, P.Q.; King, W.R. Brass satisfaction: Identifying the personal and work-related factors associated with job satisfaction among police chiefs. Police Q. 2018, 21, 250-277. [CrossRef]

35. Moghadam, S.K.; Kazemi, A. Identifying and ranking factors affecting motivation of employees. Int. Bus. Manag. 2016, 10, 2418-2423.

36. Damij, N.; Levnajić, Z.; Skrt, V.R.; Suklan, J. What motivates us for work? Intricate web of factors beyond money and prestige. PLoS ONE 2015, 10. [CrossRef]

37. Nadeem, M.; Rana, M.S.; Lone, A.H.; Maqbool, S.; Naz, K.; Ali, A. Teacher's competencies and factors affecting the performance of female teachers in Bahawalpur (Southern Punjab) Pakistan. Int. J. Bus. Soc. Sci. 2011, 2, 217-222.

38. Chatzopoulou, M.; Vlachvei, A.; Monovasilis, T. Employee's motivation and satisfaction in light of economic recession: Evidence of Grevena Prefecture-Greece. Procedia Econ. Financ. 2015, 24, 136-145. [CrossRef]

39. Kampkötter, P. Performance appraisals and job satisfaction. Int. J. Hum. Resour. Manag. 2015, 28, 750-774. [CrossRef]

40. Anguelov, K.; Stoyanova, T.; Tamošiūnienè, R. Research of motivation of employees in the it sector in Bulgaria. Entrep. Sustain. Issues 2020, 7, 2556-2567. [CrossRef]

41. Bakotic, D.; Babic, T.B. Relationship between working conditions and job satisfaction: The case of Croatian shipbuilding company. Int. J. Bus. Soc. Sci. 2013, 4, 206-213.

42. Manzoor, Q.A. Impact of employees' motivation on organizational effectiveness. Eur. J. Bus. Manag. 2011, 3, 36-45. [CrossRef]

43. Ogbonna, E.; Harris, L.C. Leadership style, organizational culture and performance: Empirical evidence from UK companies. Int. J. Hum. Resour. Manag. 2000, 11, 766-788. [CrossRef]

44. Raziq, A.; Maulabakhsh, R. Impact of working environment on job satisfaction. Procedia Econ. Financ. 2015, 23, 717-725. [CrossRef]

45. Baah, K.; Amoako, G.K. Application of Frederick Herzberg's two-factor theory in assessing and understanding employee motivation at work: A Ghanaian perspective. Eur. J. Bus. Manag. 2011, 3, 1-8. 
46. Khalid, K.; Salim, H.; Loke, S.P. The key components of job satisfaction in Malaysia water utility industry. J. Soc. Sci. 2011, 7, 550-556. [CrossRef]

47. Yang, J.T. Antecedents and consequences of job satisfaction in the hotel industry. Int. J. Hosp. Manag. 2009, 609-619. [CrossRef]

48. Monusova, G.A. Job satisfaction: International comparisons. World Econ. Int. Relat. 2008, 12, 74-83.

49. Sedliacikova, M.; Strokova, Z.; Klementova, J.; Satanova, A.; Moresova, M. Impacts of behavioral aspects on financial decision-making of owners of woodworking and furniture manufacturing and trading enterprises. Acta Fac. Xylologiae Zvolen Publica Slovaca 2020, 62, 165-176. [CrossRef]

50. Jašková, D. Assessment of social developments in Slovakia in the context of human resources. Cent. Eur. J. Labour Law Pers. Manag. 2019, 2, 21-32. [CrossRef]

51. Almobaireek, W.N.; Manolova, T.S. Entrepreneurial motivations among female university youth in Saudi Arabia. J. Bus. Econ. Manag. 2013, 14, S56-S75. [CrossRef]

52. Inceoglu, I.; Segers, J.; Bartram, D. Age-related differences in work motivation. J. Occup. Organ. Psychol. 2012, 85, 300-329. [CrossRef]

53. Arnania-Kepuladze, T. Gender stereotypes and gender feature of job motivation: Differences or similarity? Probl. Perspect. Manag. 2010, 8, 84-93.

54. Peterson, M. What men and women value at work: Implications for workplace health. Gend. Med. 2004, 1, 106-124. [CrossRef]

55. Joniakova, Z.; Blstakova, J. Age management as contemporary challenge to human resources management in Slovak companies. Procedia Econ. Financ. 2015, 34, 202-209. [CrossRef]

56. Zemke, R.; Raines, C.; Filipczak, B. Generations at Work; Amacom: New York, NY, USA, 2000.

57. Bailyn, L. SMR forum: Patterned chaos in human resource management. Sloan Manag. Rev. 1993, 34, 77-83.

58. Buttner, E.H. Female entrepreneurs: How far have they come? Bus. Horiz. 1993, 36, 59-65. [CrossRef]

59. Almobaireek, W.N.; Manolova, T.S. Who wants to be and entrepreneur? Entrepreneurial intentions among Saudi university students. Afr. J. Bus. Manag. 2012, 6, 4029-4040. [CrossRef]

60. Fratričová, J.; Kirchmayer, Z. Barriers to work motivation of generation Z. J. Hum. Resour. Manag. 2018, 2, 28-39.

61. Goić, S. Employees older than 50 on Croatian labour market-Need for a new approach. J. Hum. Resour. Manag. 2017, 2, 1-11.

62. Idrees, M.D.; Hafeez, M.; Kim, J.Y. Workers' age and the impact of psychological factors on the perception of safety at construction sites. Sustainability 2017, 9, 745. [CrossRef]

63. Freund, A.M. Age-differential motivational consequences of optimization versus compensation focus in younger and older adults. Psychol. Aging 2006, 21, 240-252. [CrossRef] [PubMed]

64. Mikkelsen, M.F.; Jacobsen, C.B.; Andersen, L.B. Managing employee motivation: Exploring the connections between managers' enforcement actions, employee perceptions, and employee intrinsic motivation. Int. Public Manag. J. 2017, 20, 183-205. [CrossRef]

65. Ngyuyen, M.L. The impact of employees motivation on organizational effectiveness; Vaasan Ammattikorkeaukoulu: Vassa, Finland, 2017.

66. Kanfer, R.; Chen, G.; Pritchard, R.D. Work Motivation: Forging New Perspectives and Directions in the Post-Millenium; Taylor \& Francis: New York, NY, USA, 2008.

67. Anderson, L.B.; Pallesen, T. "Not just for the money?" How financial incentives affect the number of publications at Danish Research Institutions. Int. Public Manag. J. 2008, 11, 28-47. [CrossRef]

68. Nguyen, L.D.; Mujtaba, B.G.; Ruijs, A. Stress, task, and relationship orientations of Dutch: Do age, gender, education, and government work experience make a difference? Public Organ. Rev. 2014, 14, 305-324. [CrossRef]

69. Hitka, M.; Kozubíková, L.; Potkány, M. Education and gender-based differences in employee motivation. J. Bus. Econ. Manag. 2018, 19, 80-95. [CrossRef]

70. Hitka, M. Model Analýzy Motivácie Zamestnancov Výrobných Podnikov; Technická Univerzita vo Zvolene: Zvolen, Slovakia, 2009.

71. Stacho, Z.; Stachova, K.; Papula, J.; Papulová, Z.; Kohnová, L. Effective communication in organisations increases their competitiveness. Pol. J. Manag. Stud. 2019, 19, 391-403. [CrossRef] 
72. Ližbetinová, L. Clusters of Czech Consumers with Focus on Domestic Brands. In Proceedings of the 29th International Business Information Management Association Conference Education Excellence and Innovation Management through Vision 2020 From Regional Development Sustainability to Global Economic Growth, Vienna, Austria, 3-4 May 2017.

73. Sedliacikova, M.; Strokova, Z.; Drabek, J.; Mala, D. Controlling implementation: What are the benefits and barries for employees of wood processing enterprises? Acta Fac. Xylologiae Zvolen Publica Slovaca 2019, 61, 163-173. [CrossRef]

74. Mura, L.; Gašparíková, V. Penetration of small and medium sized food companies on foreign markets. Acta Univ. Agric. Silvic. Mendel. Brun. 2010, 58, 157-163. [CrossRef]

75. Lizbetinova, L.; Lorincova, S.; Tikhomirova, A.; Caha, Z. Motivational Preferences among Czech and Russian Men at Managerial Positions. In Proceedings of the 31th International Business Information Management Association Conference, Education Excellence and Innovation Management through Vision 2020: From Regional Development Sustainability to Global Economic Growth, Milan, Italy, 25-26 April 2018.

76. Loucanova, E.; Olsiakova, M.; Dzian, M. Suitability of innovative marketing communication forms in the furniture industry. Acta Fac. Xylologiae Zvolen Publica Slovaca 2018, 60, 159-171. [CrossRef]

77. Cakir, O.; Kozak, M.A. Designing and effective organizational employee motivation system based on abcd model for hotel establishments. Tour. Hosp. Manag. 2017, 23, 69-86. [CrossRef]

78. Faletar, J.; Jelačić, D.; Sedliačiková, M.; Jazbec, A.; Hajdúchová, I. Motivation employees in a wood processing company before and after restructuring. BioResources 2016, 11, 2504-2515. [CrossRef]

79. Chiaburu, D.S.; Carpenter, N.C. Employees' motivation for personal initiative: The joint influence of status and communion striving. J. Pers. Psychol. 2013, 12, 97-103. [CrossRef]

80. Hitka, M.; Balazova, Z.; Grazulis, V.; Lejskova, P. Differences in employee motivation in selected countries of CEE (Slovakia, Lithuania and the Czech Republic). Inz. Ekon. 2018, 5, 536-547. [CrossRef]

81. Hitka, M.; Lorincova, S.; Bartakova, G.P.; Lizbetinova, L.; Starchon, P.; Li, C.; Zaborova, E.; Markova, T.; Schmidtova, J. Strategic tool of human resource management for operation of SMEs in the wood-processing industry. BioResources 2018, 13, 2759-2774. [CrossRef]

82. Hitka, M.; Lorincová, S.; Ližbetinová, L.; Schmidtová, J. Motivation preferences of Hungarian and Slovak employees are significantly different. Period. Polytech. Soc. Manag. Sci. 2016, 25, 117-126. [CrossRef]

83. Lizbetinova, L.; Hitka, M.; Zaborova, E.; Weberova, D. Motivational Preferences of the Czech and Russian Blue-Collar Workers. In Proceedings of the Conference of Innovation Management and Education Excellence Through Vision 2020, Milan, Italy, 25-26 April 2018. 